\title{
Serotinous cones of Cupressus sempervirens provide viable seeds in spite of high seed predation
}

\author{
Andrea BATTISTI ${ }^{\mathrm{a} *}$, Raffaella CANTINI $^{\mathrm{b}}$, Gaelle RoUAULT $^{\mathrm{c}}$, Alain RoQUES ${ }^{\mathrm{c}}$ \\ a University of Padova, DAAPV-Entomology, Agripolis, 35020 Legnaro PD, Italy \\ b Istituto Protezione Piante CNR, Via Madonna del Piano, 50019 Sesto Fiorentino Firenze, Italy \\ c INRA, Station de Zoologie forestière, BP 20619, 45166 Olivet, France
}

(Received 21 January 2002; accepted 26 August 2002)

\begin{abstract}
Five half-sib families in an 18-year old family test of Cupressus sempervirens in Italy were compared for cone crop size, cone serotiny, and seed damage. The mean number of serotinous cones per tree was significantly different among families although families did not differ by the total number of cones produced during tree's lifetime. More than $60 \%$ of the cones were colonised either by a seed chalcid, Megastigmus wachtli, or by a seed bug, Orsillus maculatus, whereas pathogenic fungi (Seiridium cardinale, Pestalotiopsis funerea) were observed in less than $25 \%$ of these cones. The quantity and quality of seeds varied significantly among families and age of cones. Seed loss due to predators and pathogens was very important in serotinous cones, varying from $75.3 \%$ up to $90.8 \%$. However, the remaining sound seeds showed a germination rate higher than $70 \%$ and cone serotiny seemed to play an important role in cypress reproductive biology.
\end{abstract}

Cupressus sempervirens / cone / serotiny / seed predation / pathogenic fungi

Résumé - Les cônes sérotineux de Cupressus sempervirens portent des graines viables même si les dégâts des ravageurs sont très importants. La production de cônes, la sérotinie et les dégâts causés aux graines ont été comparés entre cinq familles de demi-frères au sein d'un test de familles de Cupressus sempervirens de 18 ans d'âge en Italie. Des différences significatives entre familles ont été observées pour le nombre moyen de cônes sérotineux par arbre mais pas pour le nombre total de cônes produits par l'arbre au cours de sa vie. Plus de 60 \% des cônes ont été attaqués par un chalcidien des graines, Megastigmus wachtli, ou par une punaise des graines, Orsillus maculatus, mais des champignons pathogènes (Seiridium cardinale, Pestalotiopsis funerea) n'ont été observés que dans moins de $25 \%$ de ces cônes. La qualité et la quantité de graines a varié significativement entre familles et selon l'âge des cônes. La perte de graines due aux prédateurs et pathogènes a été plus importante dans les cônes sérotineux, s'élevant de 75,3\% à 90,8 \% du potentiel de départ. Cependant, les graines restées saines étaient susceptibles de germer à plus de $70 \%$. Il semble que la sérotinie joue un rôle important dans la biologie reproductive du cyprès.

Cupressus sempervirens / cône / serotinie / prédation des graines / champignons pathogènes

\section{INTRODUCTION}

Cone serotiny is defined as a canopy seed storage strategy where at least part of the previous seed crop is retained when the current year's crop of seeds is mature [11,12]. The mature, serotinous cones do not open at the end of the reproductive cycle and may remain alive on the tree for years until seed dispersal [13]. In conifers, pines have been particularly studied, fire being widely assumed to be the primary selective factor enhancing this adaptative trait $[9,14,15]$. However, serotiny seems a much higher developed strategy in Cupressaceae where 40 out of the 42 species surveyed by Lamont et al. [11] carried serotinous cones, whereas only 22 out of 95 species of Pinus and in 1 out of 17 species of Picea did so. In Cupressus sempervirens $\mathrm{L}$., first flowering occurs at the age of 3-4 years and the reproductive cycle extends over 3 years, with initiation and differentiation of flowers in the first, pollination and cone growth in the second, seed maturation and dispersal in the third year or in the first months of the fourth year [7]. Following seed dispersal, the empty cones remain open and attached to the tree for a considerable period of time but a varying number of serotinous cones may remain alive on the tree for up to 25-30 years. These cones appear to open when they loose water unlike pine cones where opening follows a melting of resin [13]. The serotiny of $C$. sempervirens thus seems to result from a selection for delayed seed dispersal determined not only by fire but also by other stress factors such as changes in water and temperature regimes, attacks by pathogens and other biotic factors [13].

\footnotetext{
*Corresponding author: andrea.battisti@unipd.it
} 
However, only a few data are available about the relationships between cone serotiny and biotic factors known to affect seeds. Becker et al. [4] showed that the reproductive success of red squirrels (Tamiasciurus hudsonicus Erxleben) is affected by the availability of serotinous cones. Although cone and seed insects are considered as the major mortality factor for seeds during the pre-dispersal phase [25], no attention has been paid to their possible impact on seed yield and seed quality in serotinous cones. However, the viability of seeds was proved to decrease with cone age in tree species with such cones, e.g. in Pinus torreyana Parry ex. Carrière [14], and it seems likely that some biotic factors, e.g. pathogens and seed predators, may contribute to this degeneration.

The interactions between forest trees, insects and pathogens are well known for non-serotinous cones. Storer et al. [25] showed that two cone beetles, Conophthorus radiatae Hopkins and Ernobius punctulatus Fall., benefit from the introduction of an exotic pathogen, Fusarium subglutinans (Wollenweb. \& Reinking) f. sp. pini, on the pine host tree in California. In Cupressus sempervirens, an association between some seed insects and seed pathogens has resulted in an optimal exploitation of the seed cones in the Mediterranean region [1,2,21]. Cypress cones may be infected by two species of pathogenic fungi, a species of North American origin responsible for the cypress bark canker (Seiridium cardinale [Wag.] Sutton \& Gibson) and a less damaging endemic species (Pestalotiopsis funerea [Desm.] Stey.) [16]. Such infected cones are frequently inhabited by the nymphs of a true seed bug (Orsillus maculatus [Fieber]), the adults of which may carry a heavy load of fungi spores at emergence [2]. The infection is thus transmitted when spore-carrying bugs lay eggs on new cones. For oviposition, the bugs frequently use holes made on the cone surface by emerging adults of a seed chalcid, Megastigmus wachtli Seitner, which colonises cypress seeds in the second year of cone development. To emerge, adult chalcids tunnel the cone scales from the seed up to the cone surface. Emergence occurs prior to seed maturation and cone opening but it may be delayed up to 2 additional years in case of prolonged larval diapause [22]. Thus, cypress trees, which bear both nonserotinous and serotinous cones, could constitute a good model to understand how serotiny may affect the interactions among the host plant, the phytophagous insects, and the tree pathogens.

In this paper, we therefore intend (i) to measure the impact of both cone and seed pests and seed pathogens on the seed reserves contained in serotinous cones of Cupressus sempervirens; (ii) to assess the importance of serotiny in the regeneration process of that tree species.

\section{MATERIALS AND METHODS}

\subsection{Study site}

The study was conducted at the Fonte dei Seppi family test, which is maintained by the National Research Council (C.N.R.) - Institute of Plant Protection of Florence. The stand was located at Monte Morello, approximately $7.5 \mathrm{~km}$ north of Florence, Italy $\left(11^{\circ} 15^{\prime} \mathrm{W}\right.$ $42^{\circ} 50^{\prime} \mathrm{N}$, elevation $610 \mathrm{~m}$ ). The trial plot was planted in 1984 with 1-year old seedlings on a moderate slope which was previously managed as a dry meadow. The test included 30 families with 40 trees per family. The trees were distributed in a random design in rows at a distance of $1 \mathrm{~m}$, and the distance between rows was $2 \mathrm{~m}$. Families were obtained from seeds of open pollinated mother trees of pyramidal form, which had been selected for resistance to Seiridium cardinale in Tuscany, Italy [18]. The trees were not subjected to thinning, pruning, cone harvesting or other cultural practices since planting, and all the produced cones were therefore susceptible to remain on tree. In 1998, we selected for the study five half-sib families showing normally grown and apparently healthy trees. They were marked according to mother trees (no. 6, 7, 13, 20, 29).

\subsection{Measurement of cone production and cone serotiny}

Six trees in each family were randomly sampled in spring and autumn 1999. The trees were selected using on a randomised series of integers [19]. Tree height and diameter at the base was measured. All the cones present on the sampled trees were collected whatever their age. The 3rd-year, just mature cones were distinguished from older ones by a lighter colour and their position on the branch but it was not possible to separate with certainty older cones of different ages. Hence, we referred to the cones in the third year of development as $\mathrm{Y} 3$ and to the older cones as $\mathrm{Y} \geq 4$. The cones in the latter category which were still closed at sampling time were considered as serotinous cones. Based on the age of the trees, we assumed that about 9-10 reproductive cycles could have been completed in the plantation since the establishment. The persistence of all open cones on the branches, confirmed by the absence of shed cones on the ground, allowed us to estimate the total number of cones produced by the trees during their lifetime, and to compare the relative importance of serotiny between trees and families.

\subsection{Estimation of cone damage due to insect pests and pathogens}

The sampled cones were stored at $+5{ }^{\circ} \mathrm{C}$ until analysis, which was completed within ten days from the collection. The partly opened Y3 and $Y \geq 4$ cones, which retained seeds within scales, were separated from the cones either closed ( $\mathrm{Y} 3$ and $\mathrm{Y} \geq 4$ serotinous cones) or open ( $\mathrm{Y} \geq 4$, free of seeds). Cones in the last category were only counted because the symptoms of fungus and insect activity were not always detected whereas cones retaining seeds were individually taken to the laboratory in plastic vials. The closed cones were also brought separately to the laboratory for analysis. The Y3 cones were counted in spring and removed in autumn.

Cones of each age category were first counted. Then, each cone was externally inspected for the presence of fungal symptoms (drying out or presence of fructifications of Seiridium cardinale and Pestalotiopsis funerea). The total number of emergence holes of the seed chalcid, Megastigmus wachtli, was counted per cone. Then, the cones were dissected scale by scale in order to assess the damage by $O$. maculatus. A first estimation was given by counting the number of bug salivary sheaths per cone, then by counting bug eggs. The respective number of egg clusters of $O$. maculatus laid in emergence holes of $M$. wachtli or within the cone scales was counted. Both unhatched and hatched eggs were considered, as egg shells remain visible for a long time in emergence holes and within scales of closed cones. The presence and species of fungi visible only inside the cone was also noted. The analysis concerned all the cones within a category, with a maximum number of 15 cones per category. This upper limit was established after a complete analysis of several samples for the total number of cones $(\geq 30)$, and a comparison tested by a $\chi^{2}$ test with subsamples of different sizes. 


\subsection{Assessing insect and fungi impact on seed yield and seed germination potential of serotinous cones}

The seeds of the first six analysed cones in each category of closed cones of each tree were extracted, placed on an adhesive paper sheet, and then X-rayed (Faxitron- $43855^{\circledR}$ ) at $20 \mathrm{Kv}$ and $3 \mathrm{~mA}$ for $4 \mathrm{~min}$. The radiographs were developed using X-ray sensitive films (Kodak ${ }^{\circledR}$ "Industrex M"). The seeds were then attributed to the categories identified by Roques and Battisti [20]; i.e., (i) filled seeds with a normal gametophyte, (ii) empty seeds without gametophyte, (iii) seeds attacked by seed bug and associated fungi, showing a brown or shrunken gametophyte, (iv) chalcid-infested seeds, showing either an adult emergence hole or a diapausing larva of $M$. wachtli. Then, the filled seeds of each cone were removed from the paper sheet to be used in a germination assay with a maximum number of 30 seeds per cone. The seeds were externally sterilised by a 10 minutes immersion in a $2 \%$ solution of sodium hypochlorite, washed three times with sterile water, spread in clear plastic Petri dishes on moist blotting paper and incubated for 30 days $20 \pm 2{ }^{\circ} \mathrm{C}$, alternating 16 hours of light and 8 of darkness. The seeds were periodically inspected during the incubation and were considered germinated when the radicle had grown at least $2 \mathrm{~mm}$ [5].

To assess the storage of viable seeds of serotinous cones, and the impact of seed predators, the potential and realised seed crop were finally calculated according to the formulas:

1. potential seed crop $=$ (no. of filled seeds + no. of damaged seeds) $\times$ germination rate $\times$ no. of serotinous cones;

2. realised seed crop $=$ no. of filled seeds $\times$ germination rate $\times$ no. of serotinous cones.

\subsection{Statistical analysis}

To compare tree size among families, the analysis of variance (ANOVA) and correlation analysis were used. Cone crop among mothers and sampling period was compared by analysis of covariance, using tree height as a covariate. The frequency of cones per cone category and the number of cones attacked by seed chalcids, seed bugs and fungi was also compared among families using analysis of variance, separately for cones $Y \geq 4$ (data pooled of partly open and closed cones) and for cones Y3 (second sampling only). When necessary, data were transformed by the $\log (\mathrm{x}+1)$ or arcsine transformation to satisfy normality and homoscedasticity. However, estimates of means are given in the untransformed scale, followed by their asymmetrical confidence limits [23]. To verify if the frequency of salivary sheaths of the seed bug was similar among families, a $\chi^{2}$ test was used.

\section{RESULTS}

\subsection{Cone production of cypress families}

A total of 7004 cones was collected from the five families (minimum 1139, maximum 1686 per family), with 1093 cones $\mathrm{Y} 3$ and 5911 cones $\mathrm{Y} \geq 4$. Total cone crop did not differ significantly among mother trees and sampling period and the data were thus pooled in the subsequent analyses. The total cone crop varied from a minimum of 14 to a maximum of 254 cones per tree, with a mean of 113.97 (st. dev. 55.30, $n=60$ ), and was significantly correlated with tree height, although the correlation was low (Pearson's $r=0.35, p<0.05$ ). However, tree height did not differ significantly among families (4.35 \pm $1.41 \mathrm{~m})$, nor did tree diameter at the base of the stem $(6.41 \pm$

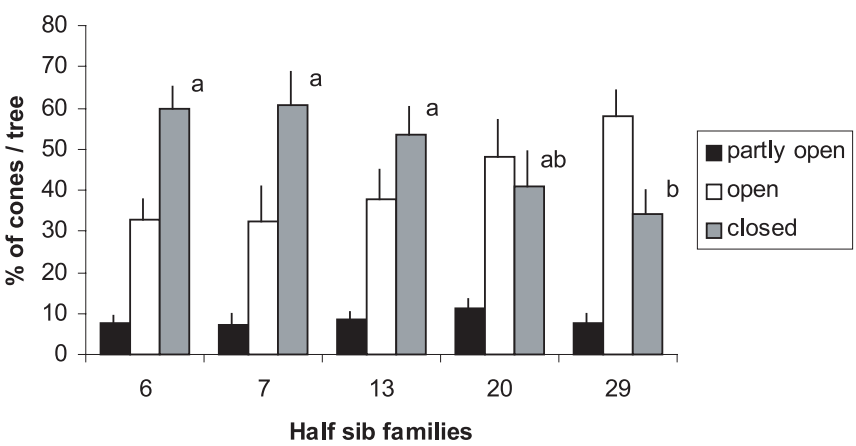

Figure 1. Average percentage (+ 1 s.e.) of cones per tree in different cone categories of five half-sib families of cypress. Serotinous cones at sampling time are indicated as "closed". "Open" cones include all cones which have already released seeds while "partly open" indicates cones still retaining seeds within open scales. Different letters indicate significant differences in pairwise comparison of means (Tukey's test, $p<0.05$ ).

$1.57 \mathrm{~cm})$, and these two variables were not significantly correlated (Pearson's $r=0.2$ ).

The number of cones in each cone category did not differ among families, with the only exception of serotinous cones (ANOVA, $\mathrm{F}_{(4,55)}=2.78, p=0.03$ ) (Fig. 1). Serotinous cones were the most numerous cones among cone categories, and they occurred with higher abundance in families 6 and 7 . The number of open cones was lower, but not significantly, in the latter families while the cones still retaining seeds within open scales were homogeneously represented among families.

\subsection{Cone colonisation by seed insects and pathogens}

Most of the sampled cones showed emergence holes of seed chalcids $(62.7 \%, n=2510)$. The frequency of cones attacked by the seed chalcid did not differ among families for both $\mathrm{Y} \geq 4$ and $\mathrm{Y} 3$ (second sampling) cones. However, the mean number of chalcid holes per cone differed significantly among families (ANOVA, $\mathrm{F}_{(4,1055)}=13.37, p<0.01$ ) (Fig. 2). Family 20 showed the highest number of emergence holes and family 29 the lowest.

Quite all cones were visited by $O$. maculatus for feeding, bug salivary sheaths being observed in $94.7 \%$ of the cones. The frequency of cones with such signs of bug probing did not differ significantly among cypress families $\left(\chi^{2}(4)=1.39, p=\right.$ $0.85)$. About $2 / 3(66.6 \%)$ of the cones were exploited by seed bugs for egg laying. The cones displaying chalcid emergence holes were almost completely colonised by bug eggs (93.4\%) whatever the family whereas the frequency of eggs laid within the cone scales was much lower (27.6\% of the total cones). In a few cases (18.7\% of cones bearing emergence holes), eggs were laid both in emergence holes and within scales. The frequency of $\mathrm{Y} \geq 4$ cones with bug eggs in emergence holes of $M$. wachtli differed significantly among families (ANOVA, $\mathrm{F}_{(4,55)}=$ $3.71, p<0.01)$, as did the number of $\mathrm{Y} \geq 4$ cones bearing eggs within scales (ANOVA, $\left.\mathrm{F}_{(4,55)}=4.81, p<0.01\right)$. In both cases, family 29 was exploited less by the seed bug for oviposition in both holes and scales. 
Table I. Results of ANOVA and mean number of seeds per cone, according to seed categories, among five half sib families ( $n=297)$. Cones $\mathrm{Y} 3$ and $\mathrm{Y} \geq 4$ were pooled because no significant differences were observed. Different letters indicate significant differences in pairwise comparison of means (Tukey's test, $p<0.05$ ). Lower and upper 95\% indicate the asymmetrical confidence interval of the mean.

\begin{tabular}{|c|c|c|c|c|c|}
\hline & $\begin{array}{l}\text { ANOVA } \\
\text { Effect: } \mathrm{F}, p\end{array}$ & Half sib family & Mean & Lower 95\% & Upper $95 \%$ \\
\hline \multirow[t]{5}{*}{ Total seeds } & Family: $\mathrm{F}_{(4,287)}=6.87, p<0.01$ & $6(\mathrm{ab})$ & 162.99 & 156.37 & 169.89 \\
\hline & Age: $\mathrm{F}_{(1,287)}=3.48, p=0.06$ & 7 (a) & 150.35 & 143.92 & 157.07 \\
\hline & & $13(b)$ & 171.26 & 160.79 & 182.42 \\
\hline & & $20(b)$ & 177.66 & 170.19 & 185.46 \\
\hline & & $29(a b)$ & 164.85 & 157.10 & 172.98 \\
\hline \multirow[t]{5}{*}{ Empty seeds } & Family: $\mathrm{F}_{(4,287)}=29.5, p<0.01$ & $6(a)$ & 47.99 & 42.56 & 54.12 \\
\hline & Age: $\mathrm{F}_{(1,287)}=2.24, p=0.14$ & 7 (b) & 72.25 & 66.89 & 78.04 \\
\hline & & 13 (a) & 55.56 & 49.71 & 62.09 \\
\hline & & $20(\mathrm{c})$ & 95.23 & 88.20 & 102.83 \\
\hline & & 29 (b) & 78.05 & 70.53 & 86.38 \\
\hline \multirow[t]{5}{*}{ Filled seeds } & Family: $\mathrm{F}_{(4,287)}=11.7, p<0.01$ & 6 (b) & 31.85 & 24.81 & 40.84 \\
\hline & Age: $\mathrm{F}_{(1,287)}=0.05, p=0.83$ & 7 (a) & 4.87 & 2.83 & 8.16 \\
\hline & & $13(b)$ & 19.40 & 12.74 & 29.40 \\
\hline & & $20(b)$ & 17.19 & 11.64 & 25.30 \\
\hline & & 29 (b) & 23.66 & 17.29 & 32.31 \\
\hline
\end{tabular}

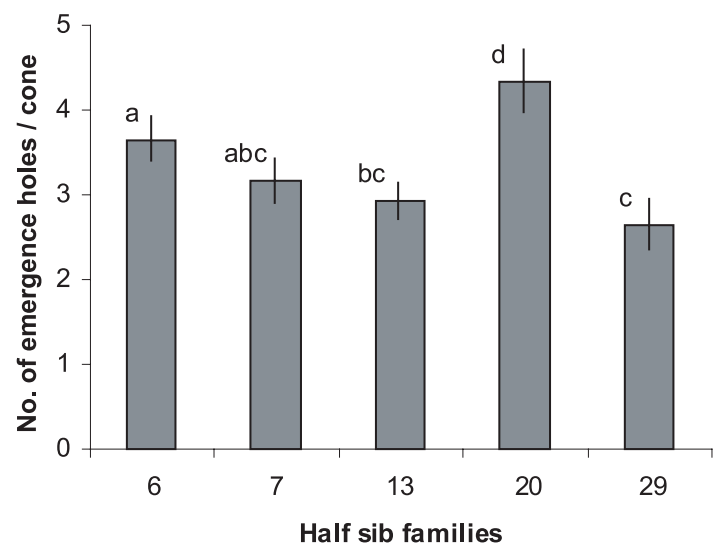

Figure 2. Mean number of emergence holes per cone of the seed wasp Megastigmus wachtli in five half-sib families of Cupressus sempervirens. Vertical bars indicate the asymmetrical $95 \%$ confidence limits of the mean. Different letters indicate significant differences in pairwise comparison of means (Tukey's test, $p<0.05$ ).

The fungi $S$. cardinale and $P$. funerea were observed in 8 and $23.9 \%$ of the $\mathrm{Y} 3$ and $\mathrm{Y} \geq 4$ cones, respectively. $S$. cardinale was the most abundant, accounting for $68.3 \%$ of the fungus-infected cones. The number of fungus-infected cones did not differ significantly among families in each cone type.

\subsection{Insect and fungi impact on seed yield and seed germination potential}

The number of total, empty, and filled seeds per cone varied significantly among families (Tab. I) but not between Y3 and $\mathrm{Y} \geq 4$ cones. The empty seeds were less represented in family 6 , which also showed the highest number of filled seeds. Conversely, family 7 had an extremely low number of filled seeds and a high number of empty seeds. The other families showed intermediate values. The frequency of seeds affected by insects and fungi differed significantly only among families $\left(\mathrm{F}_{(4,295)}=\right.$ $12.7, p<0.01$ ) (Fig. 3). Families with higher number of serotinous cones (no. 6,7,13) suffered higher damage. Seed chalcids contributed minimally to the amount of biotic damage (Fig. 2) and were thus considered together with seeds damaged by seed bugs and associated fungi. The percentage of larvae under prolonged diapause in the $\mathrm{Y} 3$ cones amounted to $31.1 \%$ of the chalcid-infested seeds but no significant differences were observed among families $\left(\chi^{2}(4)=4.11, p=0.39\right)$. In the serotinous $\mathrm{Y} \geq 4$ cones only a small proportion of larvae $(4.6 \%)$ extended their diapause for two or more years.

More than $70 \%$ of the filled seeds were capable of germinating (Fig. 4). The germination percentage was significantly affected by the family $\left(\mathrm{F}_{(4,231)}=4.15, p<0.01\right)$, the seeds in families 6 and 13 presenting a significantly lower germination (Fig. 4). On the average, the serotinous cones yielded seeds with a lower germinating capability $\left(\mathrm{F}_{(1,231)}=59.0, p<0.01\right)$ 


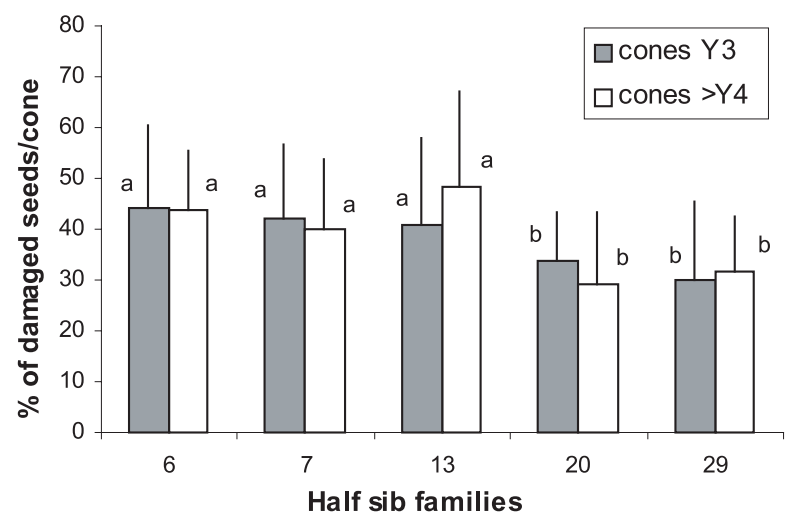

Figure 3. Percentage of seeds ( +1 s.e.) damaged by insects and fungi as determined by X-ray analysis of seeds extracted from cones of different age from five half-sib families of cypress. Different letters indicate significant differences in pairwise comparison of means (Tukey's test, $p<0.05$ ) within categories of cone age.

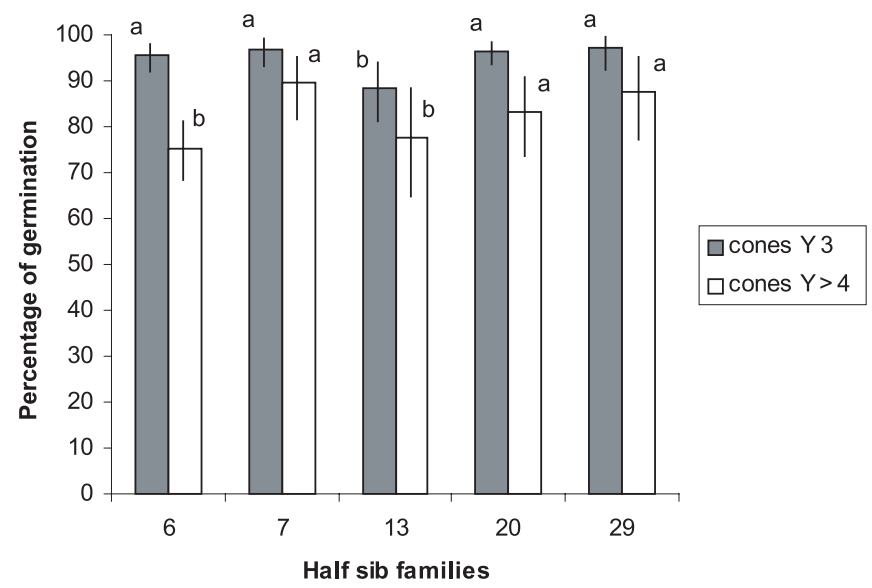

Figure 4. Mean percentage of germinated seeds per cone in cones of different age, calculated on a number of filled seeds variable from 10 to 30 per cone, among cypress half-sib families. Vertical bars indicate the asymmetrical $95 \%$ confidence limits of the mean. Different letters indicate significant differences in pairwise comparison of means (Tukey's test, $p<0.05$ ) within categories of cone age.

but within a given family a significant difference between seeds of the $\mathrm{Y} 3$ and $\mathrm{Y} \geq 4$ cones was only observed for family 6 (Fig. 4).

Finally, the potential and realised seed crops of serotinous cones were compared, to assess the storage effectiveness of such cones for the regeneration process (Fig. 5 and Tab. II). The potential number of filled, germinating seeds per tree differed significantly among families $\left(\mathrm{F}_{(4,25)}=3.46, p=0.02\right)$, as a consequence of the different level of serotiny among families (Fig. 1) and of the variable number of empty seeds (Tab. I). The realised numbers of germinated seeds were much lower than the potential numbers, the seed loss due to the joint impact of insects and fungi varying from a minimum of $75.3 \%$ (family 6) to a maximum of $90.8 \%$ (family 13). However, the total number of germinated seeds issued from serotinous cones per tree did not differ significantly among families $\left(\mathrm{F}_{(4,25)}=1.69, p=0.18\right)$.
Table II. Mean number of germinated seed per tree in serotinous cones of cypress half-sib families. Six trees per family have been considered.

\begin{tabular}{lrrrr}
\hline Half sib family & \multicolumn{1}{c}{ Mean } & St.err. & Min. & Max. \\
\hline 6 & 1751.0 & 360.3 & 715.6 & 2797.1 \\
7 & 849.2 & 373.9 & 0.0 & 2321.9 \\
13 & 715.7 & 252.5 & 64.7 & 1462.5 \\
20 & 539.3 & 283.6 & 32.5 & 1836.2 \\
29 & 217.0 & 35.2 & 116.9 & 363.5 \\
\hline
\end{tabular}

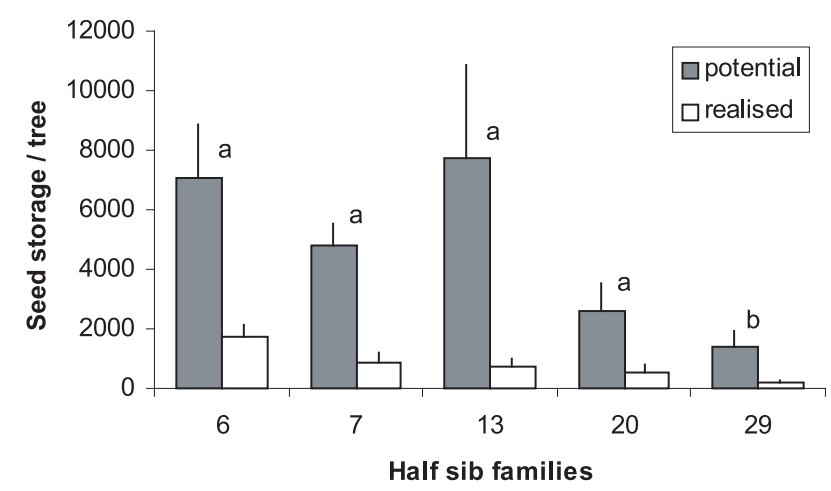

Figure 5. Mean number (+ 1 s.e.) of seeds per tree for potential $(=$ (no. of filled seeds + no. of damaged seeds $) \times$ germination rate $\times$ no. of serotinous cones) and realised seed crop $(=$ no. of filled seeds $\times$ germination rate $\times$ no. of serotinous cones) in serotinous cones of cypress half-sib families. Different letters indicate significant differences in pairwise comparison of means (Tukey's test, $p<0.05$ ).

\section{DISCUSSION}

A partial cone serotiny was observed in each of the five cypress half-sib families included in this study, but at different levels. The serotinous cones appeared to be alive and contained viable seeds, confirming previous observations made in Israel [13]. As suggested by McMaster and Zedler [14] for Pinus torreyana and Lev-Yadun [13] for Cupressus sempervirens, partial serotiny seems to be a stable trait which had been selected under a relaxed pressure of fire, which is the factor strictly related to serotiny in several pine species [9]. The occurrence of partial serotiny in all tested families may support the assumption of the stability of this trait in $C$. sempervirens. Even if it was not possible to distinguish with certainty among serotinous cones of the 9-10 cone cohorts analysed, the presence of serotinous cones of different age allows us to assume that this trait is also temporally stable in the study site. According to Lev-Yadun [13], cone serotiny in C. sempervirens is probably the result of a complex interaction of genetic and environmental factors. Cone serotiny in pines appears to be under strict genetic control $[9,15]$. Since abiotic factors are expected to affect each tree family to the same extent, it is suggested that significant differences in cone serotiny observed among cypress families are likely to be explained by genetic factors. A different serotiny level may considerably affect the 
availability of resources for pathogens and insects, especially for those which can exploit mature cones and are possibly involved in the dissemination of the fungus. Serotiny may also provide some resources in years with low or no cone crop, which can be caused for example by frost [8].

Although the seed chalcid $M$. wachtli colonises cones when they are young and soft, and therefore cannot attack serotinous cones, the latter serve as a refuge for chalcids under extended diapause [22]. Cypress tree families did not differ in attack level when the number of cones bearing at least one emergence hole was analysed, but they did for the number of emergence holes per cone. This pattern could be interpreted as a strategy to occupy all the cones, showing at the same time a higher density of emergence holes in the cones of some families (no. 20 and 6). The possibility that the plant genotype affects the susceptibility to insects exists [24, and references therein] and has been verified also in forest pests [6, 10, 17], including cone and seed insects [26].

The seed bug $O$. maculatus fed and laid eggs in almost all the cones, with a clear preference for ovipositing in the emergence holes of the seed chalcid rather than between cone scales. The different abundance of emergence holes among families may directly affect the behaviour of the seed bug O. maculatus, as it was suggested in a previous study [2]. The distribution of the seed bug eggs among cypress families would thus depend on both the colonisation and the successful development of the seed chalcid. However, in serotinous cones the recurrent partial opening of the scale may offer new possibilities for ovipositing seed bugs, especially when holes have been already occupied. The presence of serotinous cones may also give an opportunity for diapausing chalcids to create new holes years after the first emergence wave, with likely consequences on the oviposition behaviour of the seed bug. This seems to be a special feature of serotinous cones of cypress, possibly depending on their vitality and on the lack of resin coating the scales as in serotinous pines $[9,13]$.

Differences in seed quality observed among families and age of cones can be explained by factors related to host tree, seed predators, and seed pathogens. Empty seeds may result from plant traits or pollination failure because a degenerated gametophyte always remains following a colonisation by seed predators and pathogens [3]. The remaining seeds should be considered as potentially filled seeds, but only about $12 \%$ of total seeds were really filled, the rest being destroyed by seed predators and pathogens. It appears also that most of the seed damage is already done before the 4 th year of cone development. The final damage may thus result from a complex interaction of factors related to the host plant family (cone serotiny, partial opening of the scales, different susceptibility to seed predators and pathogens), to seed predators (availability of chalcid emergence holes for seed bug oviposition), and to pathogens (fungi transmission by seed bugs). The germinating power of the filled seeds partly compensate for the differences observed in their abundance among families, as lower rates of germination were found in families with high numbers of both filled seeds and serotinous cones (no. 6 and 13). The generally high rate of germination of filled seeds found in serotinous cones as well as the absence of differences between families in the final number of germinated seeds issued from such cones may support the hypothesis that cone serotiny has an impor- tant role in the reproductive biology of $C$. sempervirens. In spite of the great loss of seeds caused by insects and pathogens, the studied cypress trees still possessed a stock of 2171751 seeds capable of being dispersed and germinating several years after the cone development achieved. This strategy could provide some advantage over the formation of seed banks in soil, which may be subjected to heavy loss [9]. Thus, the permanence of serotiny in cypress populations may confer on the tree some adaptive advantages, enabling it to escape from several unfavourable factors (grazing, fire, drought, pathogens and pests) which are menacing its survival in the Mediterranean region.

Acknowledgements: We are grateful to Z. Mendel, P. Raddi, J. Turgeon, T.C.R. White and two anonymous referees for comments on an early version of this paper, and to M.C. Rosi for helping in the organisation of field work. R. Cantini was supported by a scholarship of the Italian National Research Council and G. Rouault by a scholarship of the Région Centre in France. We thank J.P. Raimbault for the X-ray analyses.

\section{REFERENCES}

[1] Battisti A., Colombari F., Frigimelica G., Guido M., Life history of Orsillus maculatus, a true bug damaging seeds of Cupressus sempervirens, in: Battisti A., Turgeon J.J. (Eds.), Proc. 5th Cone and Seed Insects IUFRO Working Party Conference, University of Padova, Padova, 1998. pp. 215-220.

[2] Battisti A., Roques A., Colombari F., Frigimelica G., Guido M., Efficient transmission of an introduced pathogen via an ancient insect-fungus association, Naturwissenschaften 86 (1999) 479-483.

[3] Battisti A., Cantini R., Feci E., Frigimelica G., Guido M., Roques A., Detection and evaluation of seed damage of cypress, Cupressus sempervirens L., in Italy, Seed Sci. Technol. 28 (2000) 199-208.

[4] Becker C.D., Boutin S., Larsen K.W., Constraints on first reproduction in North American red squirrels, Oikos 81 (1998) 81-92.

[5] Ceccherini L., Raddi S., Andreoli C., The effect of seed stratification on germination of 14 Cupressus species, Seed Sci. Technol. 26 (1998) 159-168.

[6] de Groot P., Schnekenburger F., Variation in damage by terminal shoot insects among jack pine families, For. Ecol. Manage. 121 (1999) 251-255.

[7] Giannini R., Capuana M., Giovannelli A., Plant production, in: Teissier du Cros E., Ducrey M., Barthélémy D., Pichot C., Giannini R., Raddi P., Roques A., Sales Luis J., Thibaut B. (Eds.), Cypress. A Practical Handbook, Studio Lenonardo, Firenze, 1999, pp. 45-54.

[8] Inouye D.W., The ecological and evolutionary significance of frost in the context of climate change, Ecol. Letters 3 (2000) 457-463.

[9] Keeley J.E., Zedler P.H., Serotinous pines, in: Richardson D.M. (Ed.), Ecology and biogeography of Pinus, Cambridge University Press, Cambridge, 1998, pp 110-115.

[10] Kiss G.K., Yanchuk A.D., Preliminary evaluation of genetic variation of weevil resistance in interior spruce in British Columbia, Can. J. For. Res. 21 (1991) 230-234.

[11] Lamont B.B., Le Maitre D.C., Cowling R.M., Enright N.J., Canopy seed storage in woody plants, Bot. Rev. 57 (1991) 277-317.

[12] Le Maitre D.C., Current interpretations of the term serotiny, South Afr. J. Sci. 81 (1984) 284-290.

[13] Lev-Yadun S., Living serotinous cones in Cupressus sempervirens, Int. J. Plant Sci. 156 (1995) 50-54.

[14] McMaster G.S., Zedler P.H., Delayed seed dispersal in Pinus torreyana (Torrey Pine), Oecologia 51 (1981) 62-66. 
[15] Muir P.S., Lotan J.E., Disturbance history and serotiny of Pinus contorta in Western Montana, Ecology 66 (1985) 1658-1668.

[16] Panconesi A., Raddi P., Andréoli C., Ramos P., Xenopoulos S., Caetano F., Pinto-Ganhão J., Diseases, in: Teissier du Cros E., Ducrey M., Barthélémy D., Pichot C., Giannini R., Raddi P., Roques A., Sales Luis J., Thibaut B. (Eds.), Cypress. A Practical Handbook, Studio Lenonardo, Firenze, 1999, pp. 54-73.

[17] Quiring D., Turgeon J., Simpson D., Smith A., Genetically based differences in susceptibility of white spruce to the spruce bud moth, Can. J. For. Res. 21 (1991) 42-47.

[18] Raddi P., Panconesi A., Present knowledge and perspectives in the selection of cypress genotypes resistant to the bark canker, in Panconesi A. (Ed.), Cypress, CNR- CEE, Firenze, 1991, pp. 110-115.

[19] Raj D., Sampling theory, McGraw-Hill, New York, 1968.

[20] Roques A., Battisti A., Cypress pests, in: Teissier du Cros E., Ducrey M., Barthélémy D., Pichot C., Giannini R., Raddi P., Roques A., Sales Luis J., Thibaut B. (Eds.), Cypress. A Practical Handbook, Studio Lenonardo, Firenze, 1999, pp. 75-95.
[21] Roques A., Markalas S., Roux G., Pan Y., Sun J., Raimbault J.P., Impact of insects damaging seed cones of cypress, Cupressus sempervirens, in natural stands and plantations of southeastern Europe, Ann. Sci. For. 56 (1999) 167-177.

[22] Roques A., Raimbault J.P., Cycle biologique et répartition de Megastigmus wachtli (Seitn.) (Hymenoptera, Torimidae), chalcidien ravageur des graines des cyprès dans le Bassin Méditerranéen, J. Appl. Entomol. 101 (1986) 370-381.

[23] Sokal R.R., Rohlf F.J., Biometry W.H., Freeman, New York, 1995.

[24] Stiling P., Bowdish T.I., Direct and indirect effects of plant clone and local environment on herbivore abundance, Ecology 81 (2000) 281285.

[25] Storer A.J., Wood D.L., Gordon T.R., Modification of coevolved insect-plant interactions by an exotic plant pathogen, Ecol. Entomol. 24 (1999) 238-243.

[26] Turgeon J.J., Roques A., de Groot P., Insect fauna of coniferous seed cones: diversity, host-plant interactions, and management, Ann. Rev. Entomol. 39 (1994) 179-212. 